\title{
FACTORS AFFECTING WORK MOTIVATION OF OFFICERS AND LABORERS AT VIETNAM NATIONAL UNIVERSITY OF FORESTRY, SOUTHERN CAMPUS
}

\author{
Hung Tran Van \\ Vietnam National University of Forestry, Dong Nai Province, Vietnam \\ Huong Le Thi Mai \\ HCMC University of Technology and Education, Ho Chi Minh City, Vietnam
}

The study aims to identify the main factors affecting the motivation of officials and employees at the Vietnam National University of Forestry, Southern Campus. The research team collected primary data through the survey of 215 officials working at Vietnam National University of Forestry, Southern Campus. The research methods used are descriptive statistics, exploratory factor analysis (EFA), scale test (Cronbach's Alpha), regression correlation analysis, and testing of the research hypotheses. As a result, 5 factors have been found to be affecting employees' working motivation, including: promotion opportunities and career development; wages, bonuses and benefits, stable jobs; leader; friendship colleague. On this basis, the study proposes a number of recommendations to improve the motivation of school officials.

Keywords: work motivation; factors of influence, university employees

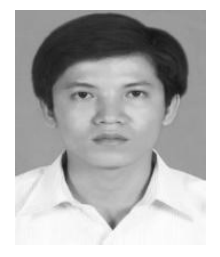

\section{Hung Tran Van}

$\mathrm{PhD}$ (The technological current status of Vietnamese enterprises with the requirements of international integration)

Lecturer Faculty of Economics, Vietnam National University of Forestry, Southern Campus, Dong Nai Province, Vietnam

Research interests - markets of agricultural products, SMEs functioning and government support, ecological economics, environmental issues of economic development and corporate social responsibility, financial management. Published more than 20 papers in International journals, member of editorial board of International journals.

E-mail: tranhungln2@gmail.com

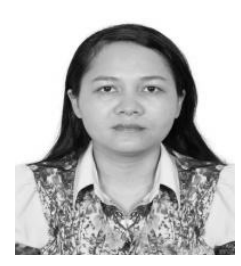

\section{Huong Le Thi Mai}

$\mathrm{PhD}$ (The technological current status of Vietnamese enterprises with the requirements of international integration)

Lecturer in Finance, University of Finance and Marketing, Ho Chi Minh, Vietnam

Science interests -financial sector, banking sector, SMEs functioning and government support, ecological economics, environmental issues of economic development and corporate social responsibility.

E-mail: : maihuongbd@gmail.com 


\section{Setting the problem}

Vietnam National University of Forestry, Southern Campus (VNUF2) is a state-owned non-business unit with specific characteristics and an extremely important responsibility to train human resources for agriculture and forestry to meet the business development requirements, namely, human resources for agriculture, forestry and rural development in South Vietnam. VNUF2 always attaches great importance to stabilizing its operations and development of human resources within the unit. The university has issued many supportive policies and appropriate rewards for both officials and employees in order to motivate them work for the School and promote the efficiency of human resources, thus creating the dynamic working space in which officials are playing an important role.

\section{Theoretical basis, model and research methods}

\section{Theoretical basis}

Applying theories and models of work motivation from the research many applied studies have been later produced, such as Ambrose \& Kulic (1999). In Vietnam, a study of similar character has been produced by Pham Thi Minh Ly (2015). The author of this article has conducted preliminary research by means of group discussion method. Through discussion, the model of working motivation of officials and employees was identified for VNUF2, in a manner similar to Kennett S. Kovach's 10-motivating model but some of the variables names have been adjusted to suit the specific situation of VNUF2 and to collect more relevant data. Thus, our 7 main factors affecting work motivation are as follows:

(1) Working environment: Linder, J.R. (1998) affirmed that safe environment presents all tools for work, a reasonable amount of working time, and a happy and well-organized workplace. Together, these parameters will create motivation for employees. Taylor, J. (2000) in their research on working motivation of nurses both confirmed that working environment affects work motivation and the level of nurse's work completion. Alderfer, C.P. (1969) made it clear that a supportive working environment of colleagues is one of the factors affecting employee's work motivation and job satisfaction.

(2) Leadership: According to Cedefop (2012) management factors have an impact on working attitude, level of dedication at work as well as motivation to complete the job well among all employee. Alderfer, C.P. (1969) explained that support on the side of management increases employees' satisfaction and creates motivation among employees. The research by Tran Kim Dung (2005) stated that employee motivation depends on leadership behavior, working relationships, corporate culture and structure, and working environment. The results of the Watson Towers study on the global workforce in 2012 emphasized that managers directly have a strong influence on employees' engagement in their jobs and their willingness to contribute to company's success.

(3) Wages, bonuses and benefits: Income and welfare are reflected in the physiological and safety needs as per Maslow's demand theory (1943), which is the most important factor for employees, at least according to the research of Cedefop (2012) in the USA, Canada or the study of Taylor, J. (2000) in the Caribbean. According to them welfare plays an important role in determining job satisfaction. Linder, J.R. (1998) analyzed salaries that are likely to motivate employees to improve their performance at work. 


\section{FACTORS AFFECTING WORK MOTIVATION}

(4) Opportunities for career advancement: According to the demand driven job theory, Alderfer, C.P. (1969) affirmation in the course of individual work is strongly influenced by three factors: achievement needs, power needs, and coalition needs. According to Truong Minh Duc (2011) the promotion opportunity factor is important for boosting employee motivation in addition to other factors. According to Tran Kim Dung (2005), training opportunity satisfies the development needs of employees. Necessary technical skills will also motivate employees to perform better, gain more achievements, they will make them want more challenging tasks along with more promotion opportunities. According to Maslow's theory, this factor means the need to be respected and asserted. In Hoang Trong \& Chu Nguyen Mong Ngoc (2005) this factor is the most important one for hotel staff in Hong Kong.

(5) Relationship with co-workers: Employees need the support of their colleagues, they find friendly comfort when working with colleagues. At the same time, employees must find their colleagues dedicated to the work to achieve the best results. Finally, colleagues need to be trustworthy (Tran Kim Dung, 2005).

(6) Empowerment: Ambrose \& Kulic (1999) argued that the lack of authority and lack of autonomy in work were the factors that contributed to reduced work motivation, which is also an increased risk factor, gradually transiting to employees' leaving the firm. According to the fundamentals of the work theory, Pham Thi Minh Ly (2015) formulated the way of work so that employees are motivated to work from within them, thus leading to job satisfaction and best work efficiency. Employees must know the work from beginning to end and the job must be of certain importance.

Secondly, the job must allow employees exercise certain rights, making them feel responsible for the results of their work. Finally, the work must ensure feedback from higher levels of organizational management, recognition of employees' achievements as well as suggestions and criticisms to help employees work better next time. It helps employees know the true outcome of their work.

(7) Job stability: According to Alderfer, C.P. (1969) the factors affecting work motivation include 2 key factors: maintenance and motivating factors, in which maintenance factors are working conditions, company policies, supervision, co-worker relations, wages, status and job stability. Under current economic crisis, job stability and regular wages become especially important factors attracting talents to the organizations that are aware of the importance of these factors.

\section{Research models}

Based on the analysis of the influencing factors and the construction of the above scale, the author recommends a model to study the factors affecting the motivation of university officials and employees.

The research model consists of 7 elements, and the author discusses this group of elements to formulate an official questionnaire suitable to the actual situation in VNUF2, using 35 observed variables to measure the general level of motivation.

All the observed variables are measured using the 5-step Lickert scale with the corresponding level: Level 1 is completely disagreeing with a statement, Level 2 means disagreeing, Level 3 is normal, Level 4 stands for agreeing and Level 5 is completely agreeing with the statement. The result has been the official questionnaire to be used in the course of a survey. 
Based on the research model, the hypotheses in this study are formulated as follows:

$\mathrm{H} 1$ : Working environment contributes to improving working motivation.

$\mathrm{H} 2$ : The interest of leadership increases work motivation.

H3: Salary, bonus, and welfare have a positive relationship with work motivation.

H4: Opportunity for promotion and career development helps improve work motivation.

H5: Relationships with colleagues contribute to increased work motivation.

H6: Leadership empowers employees to contribute to improving work motivation.

H7: Job stability motivates work motivation.

\section{Research methods}

\section{Data collection}

Secondary data is collected from the legal documents of the Ministry of Education and Training, the General Statistics Office reports, the annual general reports; documents; decrees; guiding circulars; regulations on annual internal spending; reports of the functional departments of VNUF2. Primary data will be collected through surveys, interviews with school officials and staff following the prepared questionnaire. The survey method involves direct interviews with officials in charge of the office work because it is advantageous that they are working full-time at the School from Monday to Friday. For officials who are lecturers, the methods of investigation are direct interviewing or emailing.

Methods of sample selection

The data analysis method used in this study is analysis based on the exploratory factor analysis model. In order to obtain reliable estimations on this method, the sample usually has to be large enough. Stemming from Hair et al. (2010), the minimum sample size for the exploratory factor analysis model is at least 5 observations (preferably 10 or more observations) for an estimated parameter amount, the theoretical model has 7 observations with 35 parameters to be estimated, so the minimum sample size required for formal research is conducting a survey of 215 out of 218 officials, thus resulting in 205 questionnaires collected from initial 215 questionnaires given out. After eliminating invalid questionnaires because they had blank cells or because the respondents chose more than one answer, 202 questionnaires were used for analysis and verification, and the selected sample met the criteria on both number and content.

Methods of processing and analysis

The study used IBM SPSS 23.0 statistical analysis software to analyze the EFA discovery factor for identifying the factors that affect the motivation of employees at Vietnam National University of Forestry, Southern Campus. Based on the analysis results, the study proposes a number of recommendations to improve the working motivation for officials and employees on this campus.

\section{Research results}

\section{Evaluation of scale}

Evaluation using Cronbach Alpha coefficient test

The scale and reliability of the observed variables have been assessed using Cronbach's Alpha coefficients and Exploratory Factor Analysis (EFA). The Cronbach Alpha coefficient 


\section{FACTORS AFFECTING WORK MOTIVATION}

has been used to evaluate the convergence of the components in the scale to eliminate the nonconforming variables of the study.

The variables with a correlation/total correlation (Corrected Item - Total correlation) of less than 0.3 will be excluded and criteria for the scale were selected when it had an Alpha reliability of 0.6 or more. Moreover, in the course of EFA discovery factor analysis, variables with factor loading factor of less than 0.5 will be removed from the scale because of poor correlation with the underlying factor.

The final step is to test the model by means of multivariate regression with the statistical significance of 5\%. As mentioned above, we have 8 scales for 8 research concepts, including 7 concepts that are 7 components affecting employee motivation, labor and the working motivation concept. The scales of these concepts are preliminarily assessed through the Cronbach alpha reliability coefficient and the EFA discovery factor analysis method with the data collected in the course of the research. Cronbach alpha test results are presented in Table 1.

Table 1 - Results of Cronbach's Alpha test of quality scale of the working motivation components for the officials at VNUF2

(Source: Calculated as per 2020 survey data)

\begin{tabular}{|c|l|c|c|}
\hline No. & \multicolumn{1}{|c|}{ Variable groups } & $\begin{array}{c}\text { Number of } \\
\text { variables }\end{array}$ & $\begin{array}{c}\text { Cronbach's } \\
\text { Alpha }\end{array}$ \\
\hline 1 & Working environment & 5 & 0.851 \\
\hline 2 & Leadership & 6 & 0.901 \\
\hline 3 & Salary and benefits & 7 & 0.923 \\
\hline 4 & $\begin{array}{l}\text { Career promotion and career } \\
\text { development opportunities }\end{array}$ & 5 & 0.888 \\
\hline 5 & Relationship with colleagues & 4 & 0.707 \\
\hline 6 & Empowerment & 5 & 0.785 \\
\hline 7 & Job stability & 3 & 0.815 \\
\hline
\end{tabular}

From the Cronbach's Alpha test results, it shows that the scale of the working motivation factors is reliable. The observed variables have total correlation coefficient $>0.3$ and Cronbach's Alpha coefficients are greater than 0.6. Therefore, all measurement variables will be used in subsequent analyzes.

EFA discovery factor analysis

(1) Independent variables:

When performing EFA for the first time, the analysis results showed that QHDN2 variable had a loading factor $<0.5$. Therefore, this variable was excluded.

After conducting the second round of EFA, the results are presented in Tables 3 and 4. 
Table 2 - KMO and Bartlett test results

(Source: Calculated from the 2020 survey data)

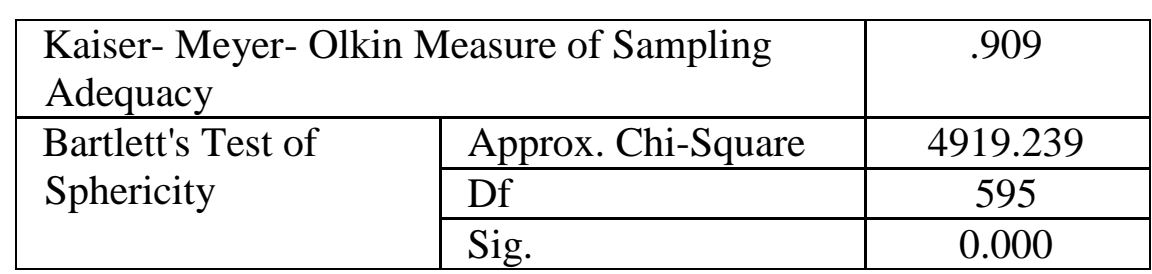

In Table 2, we have KMO $=0.09$ which is satisfying the condition $<0.5 \mathrm{KMO}<1$, so the discovery factor analysis is suitable for real data.

Table 3 - Results of EFA analysis for independent variables

Rotated Component Matrix

(Source: Calculated from the 2020 survey data)

\begin{tabular}{|c|c|c|c|c|c|c|c|}
\hline & \multicolumn{7}{|c|}{ Components } \\
\cline { 2 - 8 } & 1 & 2 & 3 & 4 & 5 & 6 & 7 \\
\hline LT1 & .811 & & & & & & \\
\hline LT2 & .792 & & & & & & \\
\hline LT4 & .747 & & & & & & \\
\hline LT3 & .690 & & & & & & \\
\hline LT6 & .663 & & & & & & \\
\hline LT5 & .615 & & & & & & \\
\hline LT7 & .592 & & & & & & \\
\hline$\ldots$ & & $\ldots$ & $\cdots$ & $\cdots$ & $\cdots$ & $\cdots$ & .740 \\
\hline C02 & & & & & & & \\
\hline C01 & & & & & & & .690 \\
\hline C03 & 12.731 & 3.160 & 2.760 & 1.907 & 1.484 & 1.261 & 1.158 \\
\hline Eigen values & 36.374 & 9.028 & 7.887 & 5.449 & 4.241 & 3.603 & 3.309 \\
\hline Extracted variance (\%) & .851 & .901 & .923 & .888 & .707 & .785 & .815 \\
\hline Cronbach's alpha & & & & & & \\
\hline
\end{tabular}

Table 3 shows the results of the EFA analysis for the independent variables:

- 7 ingredients have been extracted;

- Eigen value is > 1 with the total variance extracted being $69.891 \%$;

- KMO coefficient is 0.909 (while its satisfactory value is >0.5);

- Bartlett's test for the achieved statistical significance level Sig $=0.000$ (satisfactory Sig <0.05): observed variables are correlated with each other in the whole;

- Factor load factors of the observed variables are greater than 0.5. Thus, these scales meet the requirements corresponding to the research concepts and will be included in the next official quantitative research sections.

(2) Dependent variables:

The EFA analysis results for the dependent variable are presented in Tables 4 and 5 . 
FACTORS AFFECTING WORK MOTIVATION

Table 4 - KMO and Bartlett test results for the dependent variables

(Source: Calculated from the 2020 survey data)

\begin{tabular}{|l|c|c|}
\hline \multicolumn{2}{|c|}{ Kaiser-Meyer-Olkin Measure of Sampling Adequacy } & 0.845 \\
\hline Bartlett's Test of Sphericity & Approx. Chi-Square & 802.272 \\
\cline { 2 - 3 } & Df & 10 \\
\cline { 2 - 3 } & Sig. & .000 \\
\hline
\end{tabular}

Table 5 - EFA analysis results for the dependent variable

(Source: Calculated from the 2020 survey data)

\begin{tabular}{|l|c|}
\hline \multicolumn{1}{|c|}{ Observed variables } & Factor \\
\cline { 2 - 2 } & 1 \\
\hline working motivation 1 & .668 \\
\hline working motivation 2 & .806 \\
\hline working motivation 3 & .825 \\
\hline working motivation 4 & .801 \\
\hline working motivation 5 & .744 \\
\hline Eigen values & 3.845 \\
\hline Variance of extraction $\mathbf{( \% )}$ & 76.893 \\
\hline Cronbach Alpha & 0.923 \\
\hline
\end{tabular}

The results of the factor analysis for the 5 observed variables of the working motivation scale are as follows:

- There is 1 extract component;

- Eigen value value is 3,845 (thus meeting the requirement of Eigen value being >1) with the total deduction variance being $76,893 \%$;

- KMO coefficient is 0.845 (the satisfactory level being >0.5). Thus, factor analysis consistent with the research data.

- Bartlett's test achieved the statistical significance level ar Sig $=0.000$ (satisfactory Sig <0.05): the observed variables are correlated with each other in the whole.

- Factor load factors of the observed variables are greater than 0.5.

The variables measuring the working motivation components are used in the subsequent analysis.

\section{Correlation analysis and regression}

\section{Correlation analysis}

Correlation analysis was performed for the working motivation dependent variable (DLLV) and the following independent variables: working environment (MT), leadership (LD), salary and welfare (LP), promotion opportunities and career development (CHNN), relationship with colleagues (QHDN), empowerment and job stability (CO). Pearson's correlation analysis was applied here. The results are presented in Table 6. 
Table 6 - Results of the correlation analysis

(Source: Calculated from the 2020 survey data)

\begin{tabular}{|c|c|c|c|c|c|c|c|c|c|}
\hline & & 坣 & $\underline{E}$ & 9 & 9 & 党 & 号 & $\underset{\sim}{O}$ & O \\
\hline \multirow{2}{*}{$\begin{array}{l}\text { Working } \\
\text { motivation }\end{array}$} & $\begin{array}{l}\text { Correlation coefficients } \\
\text { Pearson }\end{array}$ & - & ले & 華 & $\stackrel{\text { * }}{\stackrel{*}{2}}$ & $\stackrel{*}{*}$ & $\stackrel{6}{ \pm}$ & : & $\frac{*}{6}$ \\
\hline & Sig. (2-tailed) & & 8 & 8 & 8 & 8 & 8 & 8 & 8 \\
\hline \multirow{2}{*}{$\begin{array}{l}\text { Working } \\
\text { environment }\end{array}$} & $\begin{array}{c}\text { Correlation coefficients } \\
\text { Pearson }\end{array}$ & & - & $\stackrel{2}{9}$ & 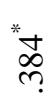 & in & $\stackrel{\infty}{1}$ & กุ & ָे \\
\hline & Sig. (2-tailed) & & & $\stackrel{n}{\pi}$ & $\stackrel{\nabla}{\sigma}$ & $\overline{\widehat{N}}$ & $\stackrel{m}{5}$ & $\stackrel{\infty}{\infty}$ & $\stackrel{n}{q}$ \\
\hline \multirow{2}{*}{ Leadership } & $\begin{array}{c}\text { Correlation coefficients } \\
\text { Pearson }\end{array}$ & & & - & $\underset{0}{0}$ & $\stackrel{*}{*}$ & 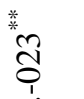 & 安 & $\frac{m}{n}$ \\
\hline & Sig. (2-tailed) & & & & $\stackrel{\infty}{8}$ & $\S$ & 8 & 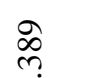 & 8 \\
\hline \multirow{2}{*}{$\begin{array}{l}\text { Salary and } \\
\text { welfare }\end{array}$} & $\begin{array}{c}\text { Correlation coefficients } \\
\text { Pearson }\end{array}$ & & & & - & है. & $\stackrel{*}{*}$ & \%o & $\begin{array}{l}{ }^{*} \infty \\
n \\
n\end{array}$ \\
\hline & Sig. (2-tailed) & & & & & 8 & 8 & 8 & 8 \\
\hline \multirow{2}{*}{$\begin{array}{l}\text { Promotion } \\
\text { opportunities } \\
\text { and career } \\
\text { development }\end{array}$} & $\begin{array}{c}\text { Correlation coefficients } \\
\text { Pearson }\end{array}$ & & & & & 一 & ". & 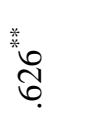 & $\stackrel{*}{n}$ \\
\hline & Sig. (2-tailed) & & & & & & 8 & 8 & 8 \\
\hline \multirow{2}{*}{$\begin{array}{l}\text { Relationship } \\
\text { with } \\
\text { colleagues }\end{array}$} & $\begin{array}{c}\text { Correlation coefficients } \\
\text { Pearson }\end{array}$ & & & & & & - & : & 葛 \\
\hline & Sig. (2-tailed) & & & & & & & 8 & 8 \\
\hline \multirow{2}{*}{$\begin{array}{c}\text { Empowermen } \\
\mathrm{t}\end{array}$} & $\begin{array}{c}\text { Correlation coefficients } \\
\text { Pearson }\end{array}$ & & & & & & & - & 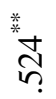 \\
\hline & Sig. (2-tailed) & & & & & & & & 8 \\
\hline \multirow[t]{2}{*}{ Job stability } & $\begin{array}{c}\text { Correlation coefficients } \\
\text { Pearson }\end{array}$ & & & & & & & & - \\
\hline & Sig. (2-tailed) & & & & & & & & \\
\hline
\end{tabular}


The correlation analysis results in Table 6 show that all the independent variables of the work environment, leadership, bonuses and welfare, opportunities for career advancement and development, co-worker relations, empowerment and job stability are linearly correlated with the dependent variable at the $1 \%$ significance level. Therefore, these independent variables can be included in the next regression analysis to explain the influence of the dependent variable in our research model.

\section{Regression analysis}

The regression equation shows the relationship between the dependent variable that is work motivation (DLLV) and the independent variables that are working environment (MT), leadership (LD), salary and benefits ( LP), promotion and career development opportunities $(\mathrm{CHNN})$, co-worker relations (QHDN), empowerment (TQ) and job stability (CO). Regression analysis helps us know the extent of the influence of different independent variables on the dependent variable using the following regression model:

$$
\mathrm{DLLV}=\beta_{0}+\beta_{1} \mathrm{MT}+\beta_{2} \mathrm{LD}+\beta_{3} \mathrm{LP}+\beta_{4} \mathrm{CHNN}++\beta_{5} \mathrm{QHDN}++\beta_{6} \mathrm{TQ}++\beta_{7} \mathrm{CO}
$$

The determination coefficient $\mathrm{R}^{2}$ is used to assess the suitability of the research model. The determination coefficient $\mathrm{R}^{2}$ has been shown to be a non-decreasing function with the number of independent variables included in the model. However, it has also been shown that the more variables an equation has, the better it is for the data. Thus, $\mathrm{R}^{2}$ tends to be an optimistic estimate of the model's suitability for the data in case there is more than one explanatory variable in the model. The model usually does not match the actual data as the $\mathrm{R}^{2}$ value shows. Therefore, the adjusted $\mathrm{R}^{2}$ value (Adjusted $\mathrm{R}$ Square) will be used to better reflect the suitability of the multivariate linear regression model (Hoang Trong \& Chu Nguyen Mong Ngoc, 2005).

Table 7 - Testing the suitability of the model (Source: made by the authors)

\begin{tabular}{|l|l|c|c|c|c|c|}
\hline Model & & Sum of squares & df & $\begin{array}{c}\text { Medium } \\
\text { square }\end{array}$ & F & Sig. \\
\hline \multirow{3}{*}{} & Regression & 74.307 & 7 & 10.615 & 85.870 & .000 \\
\cline { 2 - 7 } & Residual & 23.982 & 194 & .124 & & \\
\cline { 2 - 7 } & Total & 98.289 & 201 & & & \\
\hline
\end{tabular}

Table 8. Summary of the regression model (Source: made by the authors)

\begin{tabular}{|c|c|c|c|c|c|c|c|c|c|}
\hline \multirow[b]{2}{*}{ Model } & \multirow[b]{2}{*}{$\mathrm{R}$} & \multirow{2}{*}{$\begin{array}{c}\mathrm{R} \\
\text { Square }\end{array}$} & \multirow[b]{2}{*}{$\begin{array}{c}\text { Adjusted R } \\
\text { Square }\end{array}$} & \multirow[b]{2}{*}{$\begin{array}{l}\text { Std. Error of } \\
\text { the Estimate }\end{array}$} & \multicolumn{5}{|c|}{ Change Statistics } \\
\hline & & & & & $\begin{array}{c}\text { R Square } \\
\text { Change }\end{array}$ & F Change & df1 & df 2 & $\begin{array}{l}\text { Sig. F } \\
\text { Change }\end{array}$ \\
\hline 1 & $.869^{\mathrm{a}}$ & .756 & .747 & .35160 & .756 & 85.870 & 7 & 194 & .000 \\
\hline
\end{tabular}


Table 9 - Statistical parameters of each independent variable in the model (Source: made by the authors)

\begin{tabular}{|c|c|c|c|c|c|c|c|}
\hline \multirow{2}{*}{ Model } & \multicolumn{2}{|c|}{$\begin{array}{c}\text { Unstandardized } \\
\text { Coefficients }\end{array}$} & \multirow{2}{*}{$\begin{array}{r}\text { Standardized } \\
\text { Coefficients } \\
\text { Beta }\end{array}$} & \multirow[t]{2}{*}{$\mathrm{T}$} & \multirow{2}{*}{ Sig. } & \multicolumn{2}{|c|}{ Collinearity Statistics } \\
\hline & $\mathrm{B}$ & Std. Error & & & & Tolerance & VIF \\
\hline \begin{tabular}{|l|} 
(Constant) \\
\end{tabular} & -.390 & .224 & & -1.742 & .083 & & \\
\hline $\mathrm{CO}$ & .211 & .052 & .193 & 4.041 & .000 & .553 & 1.808 \\
\hline QHDN & .073 & .033 & .081 & 2.220 & .008 & .933 & 1.072 \\
\hline MT & .025 & .041 & .025 & .614 & .540 & .787 & 1.270 \\
\hline TQ & .072 & .054 & .071 & 1.335 & .183 & .445 & 2.247 \\
\hline CHNN & .409 & .055 & .392 & 7.399 & .000 & .449 & 2.227 \\
\hline LD & .136 & .039 & .154 & 3.510 & .001 & .650 & 1.539 \\
\hline LP & .248 & .060 & .231 & 4.112 & .000 & .400 & 2.498 \\
\hline
\end{tabular}

Set of the hypotheses $\mathrm{H}_{0}: \beta_{1}=\beta_{2}=\beta_{3}=\beta_{4}=\beta_{5}=\beta_{6}=\beta_{7}=0$

In Table 7, the F-statistics is 85.870 calculated from the $\mathrm{R}^{2}$ value of the full model, and the Sig value is very small $(<0.000)$. Thus, it would be rather safe to reject the hypothesis $\mathrm{H}_{0}$ said that $\beta_{1}=\beta_{2}=\beta_{3}=\beta_{4}=\beta_{5}=\beta_{6}=\beta_{7}=0$.

The given linear regression model is suitable for data and usable for independent variables in the model that are linearly correlated with the dependent variable.

In Table 8 , the $\mathrm{R}^{2}$ value of 0.756 is quite high, thus proving the model's suitability. On the other hand, the research results show that the $R^{2}$ adjusted by 0.747 is smaller than $R^{2}$, that is, the linear regression model is built in accordance with $74.7 \%$ of the data.

The results in Table 9 are used to test the linear relationship between the working motivation dependent variable and the independent variables of environment, leadership, wages, bonuses and benefits, career opportunities, co-worker relations, rights and job stability so that to consider whether working motivation is linearly related to these independent variables. Among the 7 independent variables, 5 variables affecting work motivation with Sig $<5 \%$ are: job stability, co-worker relationship, opportunities for promotion and career development, leadership, remuneration and other benefits. And the remaining 2 variables working environment and empowerment - are not statistically significant because Sig. is greater than 5\%. The tolerance coefficients are quite high (from 0.445 to 0.933 ) and the magnification coefficients of variance (VIF) are low (from 1.072 to 2.498), thus, shown in the regression model the relationship between the independent variables is negligible. And no multi-collinear phenomena are observed here.

Now we can test the model's implicit assumptions: 
FACTORS AFFECTING WORK MOTIVATION

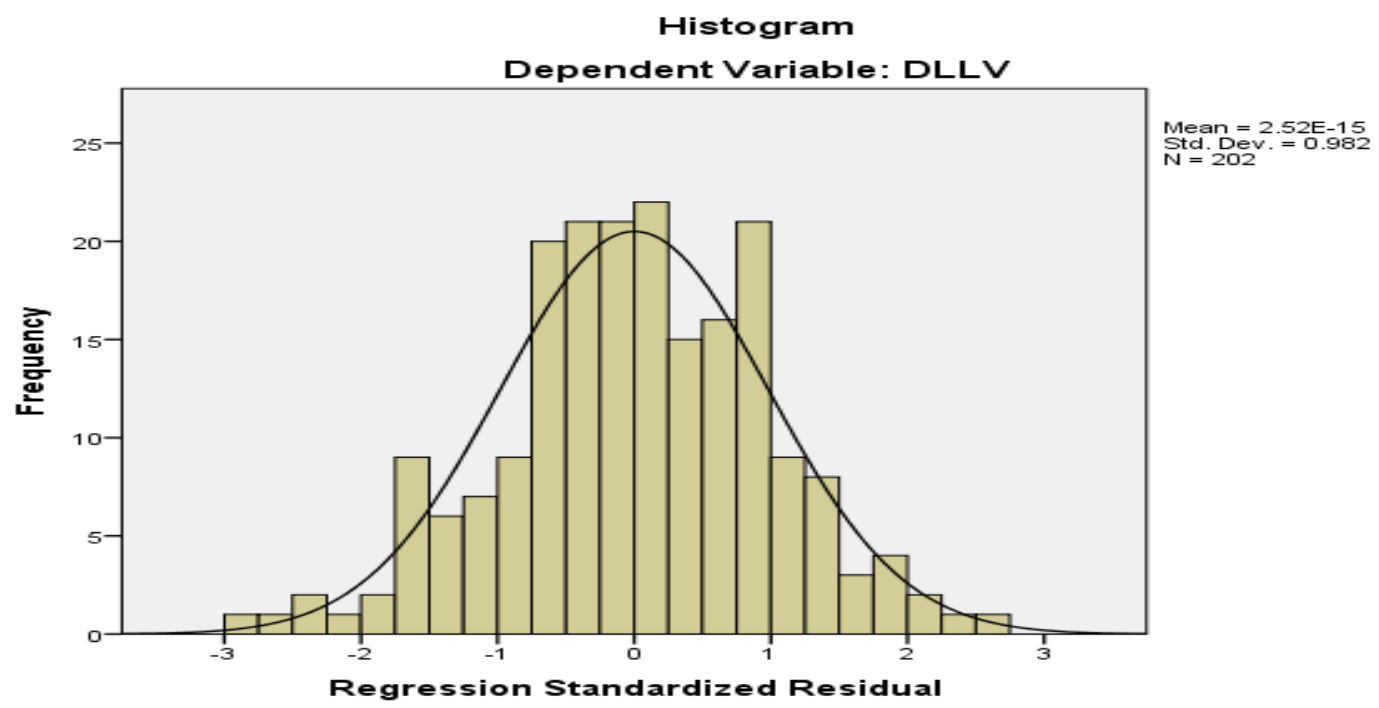

Figure 1 - Standard distribution of residuals

(made by the authors)

The chart above shows the standard distribution of the standard residual approximately Mean $=2.52 \mathrm{E}-15$ and the standard deviation Std. Dev $=0.982$, which is close to 1 . Therefore, it is possible to conclude that the hypothesis regarding normal distribution of the residuals is not violated.

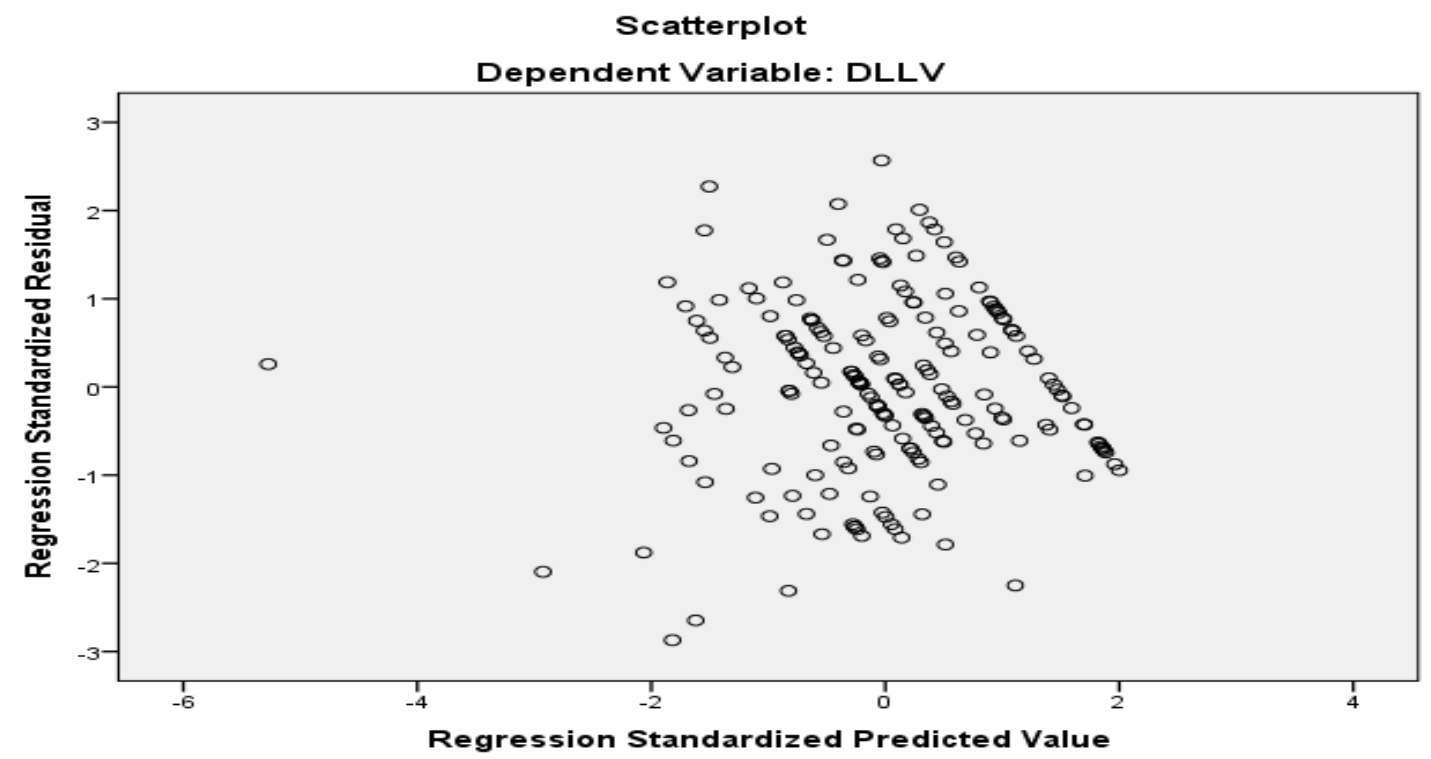

Figure 2 - Scatterplot chart

(made by the authors)

The scatterplot chart above shows even dispersion.

The assumptions of the linear regression function are not violated and the regression model developed is overall suitable. According to our calculation results, the regression equation looks as follows:

$$
\text { DLLV }=-0.390+0.409 \mathrm{CHNN}+0.248 \mathrm{LP}+0.211 \mathrm{CO}+0.136 \mathrm{LD}+0.073 \mathrm{QHDN} \text {. }
$$


The linear regression equation above shows that opportunities for advancement and career development, wages, bonus and welfare, job stability, leadership and relationship with colleagues strongly impact, in the descending order, on the motivation of school officials. More specifically:

The regression coefficient of the promotion and career development variable is 0.392 , it has a positive impact on the dependent variable and this is the component that has the most impact on employee motivation. The opportunity for promotion and career development satisfies the needs at work and helps officials achieve the goals of career development. Thus, it will motivate them to continue trying to improve their skills and knowledge while pursuing their careers further.

The regression coefficient of bonus and welfare variables is 0.231 . Bonuses and benefits will have the same impact on the motivation of officials. This is also consistent with the research on Maslow's Demand Theory (1943). Wages, bonuses and benefits are the tools stimulating material benefits for employees. They motivate employees to do well in order to ensure organizational goals, maintain the quantity and the quality of labor.

The regression coefficient of job stability is 0.193 . This variable works in the same direction with the work motivation of officials. This is consistent with the research of Frederick Herzberg (1959). Every employee desires to have a stable job, this comes from the need to stabilize people's lives. In fact, when workers have stable jobs, their mentality will be more stable and their concentration on work will be higher, they will strive harder to achieve higher results while working.

The regression coefficient of leadership variable is 0.154 . Leadership has a positive impact as it helps officials increase their motivation to work.

Leadership here is understood as a method that a leader uses to influence subordinates or employees to achieve certain goals or results. Experience and leadership styles directly affect the atmosphere and motivation among employees. It is the attention and support of management that increases employee satisfaction and creates motivation for employees. In addition, direct managers have a strong influence on employees' engagement in their jobs, their attachment to their structural units and their willingness to contribute to business success.

The regression coefficient of co-worker variable is 0.081 . This factor has a positive impact on the motivation of officials. When colleagues are friendly, comfortable, and reliable and willing to help each other, this support will motivate both workers and managers.

\section{The results of the research hypotheses' testing}

According to our test results, we can accept five hypotheses $-\mathrm{H}_{2}, \mathrm{H}_{3}, \mathrm{H}_{4}, \mathrm{H}_{5}$ and $\mathrm{H}_{7}$. The hypotheses $\mathrm{H}_{1}$ and $\mathrm{H}_{6}$ are thus rejected.

The results of testing the impact of factors on work motivation are as follows: 
FACTORS AFFECTING WORK MOTIVATION

Table 10 - Summary on testing the research hypotheses (made by the authors)

\begin{tabular}{|c|l|c|c|}
\hline Hypothesis & \multicolumn{1}{|c|}{ Content } & P-value & Result \\
\hline H1 & $\begin{array}{l}\text { Working environment contributes to } \\
\text { improved working motivation }\end{array}$ & $0.0540>0.05$ & Rejected \\
\hline H2 & $\begin{array}{l}\text { The interest of leadership increases work } \\
\text { motivation }\end{array}$ & $0.001<0.05$ & Accepted \\
\hline H3 & $\begin{array}{l}\text { Wages, bonuses and benefits have a } \\
\text { positive relationship with work } \\
\text { motivation }\end{array}$ & $0.000<0.05$ & Accepted \\
\hline H4 & $\begin{array}{l}\text { Promotion opportunities and career } \\
\text { development help improving work } \\
\text { motivation }\end{array}$ & $0.000<0.05$ & Accepted \\
\hline H5 & $\begin{array}{l}\text { Relationships with colleagues contribute } \\
\text { to increased work motivation }\end{array}$ & $0.028<0.05$ & Accepted \\
\hline H6 & $\begin{array}{l}\text { Leadership empowers employees to } \\
\text { improve their motivation }\end{array}$ & $0.183>0.05$ & Rejected \\
\hline H7 & Job stability motivates workers & $0.000<0.05$ & Accepted \\
\hline
\end{tabular}

\section{Conclusions and recommendations}

\section{Conclusion}

Through the actual survey of school officials, the study regression model has identified the factors affecting the working motivation of officials and employees at VNUF2. These factors include: opportunities for promotion and career development; salaries, bonuses and benefits; leadership; co-worker relations; job stability. Of particular importance are such factors as promotion and career development opportunities; salaries, bonuses and benefits; leadership; co-worker relations and job stability. More specifically, opportunities for promotion and career development are the components that most impact on employee motivation.

In general, these factors are in accordance with the research results of domestic and foreign scholars and real life conditions of the University itself. Further, the research team has proposed a number of recommendations that may contribute to improving work motivation among school officials.

\section{Recommendations}

Career promotion and development opportunities:

This is a factor that greatly affects the motivation of officials and employees. In order to create opportunities for promotion and career development for officials and employees and to ensure the maximization of knowledge and experience among officials and employees, the school needs to use human resources in the right position and professional qualifications. The use of "the right people for the right jobs" would greatly help both officials and employees develop all their talents and feel treated with much respect. This is also a measure that would help them stick with the University for a longer time. In order to accomplish this, the school 
needs to build and put into use the system of measurement and evaluation of work efficiency and on that basis - to assess the level of work performance among officials and employees as a basis for payment of salaries, bonuses, allowances, reviews, salary increase, promotion, etc. The school has a policy to create favorable conditions for officials and employees in terms of promoting their career, giving them appropriate jobs and developing their strengths. The school continues to create conditions for officials and employees to participate in learning and thus improve their professional qualifications, to meet job requirements and enjoy career development in the future. The school plans to hold a contest of good teachers, good experts, to send lecturers to participate in the contest of good teachers at the ministerial level etc. in order to create the conditions for officials and employees to have the opportunity to show their personal competences to a larger public and thus get self-affirmation. In addition, officials and employees must always have the sense of responsibility, dedication to the assigned work, working for the common goals of the School, trying to fulfill the tasks assigned by the School and its units. At the same time, officials and employees must constantly improve their professional qualifications to serve at work and show their individual capacity in front of the collective and the school.

Motivating employees to work with remuneration policies including wages, bonuses and benefits:

This is an important factor for improving the motivation of school officials. In order for the remuneration policy to effectively serve the promotion of all officials towards the longterm development goals of the University, remuneration policies should be formulated according to the following principles: they must be made public so that all members can fully understand the School's remuneration mechanism. To accomplish this, each unit needs a description for each specific job position of the officer in charge of the unit in order to help the unit assess the level of work done by officials and help officials see their position, role and contribution as other members of the school do.

In addition, the school needs to maintain and gradually increase wages, bonuses and benefits for both officials and employees in the following years. However, this would depend on many objective and subjective factors. In addition to the material rewards, non-tangible rewards such as the School's certificate of merit, the words of praise and encouragement are very important for both officials and employees. Other forms of allowances are also important, such as seniority allowances for teachers, extra pay for overtime, position allowances, hazardous work conditions allowances etc. Depending on a specific situation, the school should pay these allowances appropriately in order to provide a part of the school officials' income and help them feel the school's interest in them. Officials themselves need to practice saving and combate own wastefulness with practical actions such as saving electricity, saving stationery etc. This would contribute to the increase of the school's general income. The school has a way of rewarding officials and employees who have the sense of thrift, and at the same time rebuke those officials who waste resources supplied to them.

\section{Job stability:}

Stability and safety at work are always indispensable factors for employees. The precarious situation at work has the ability to greatly affect productivity, morale and confidence of people. According to Frederick Herzberg (1959), job stability includes maintenance factors and motivating factors. Maintenance factors are working conditions, school policies, supervision, co-worker relations, wages, stable positions and jobs. Under current economic crisis conditions especially, job stability and regular salary are highly 


\section{FACTORS AFFECTING WORK MOTIVATION}

important factors attracting new employees to work permanently at the University. Therefore, the School should be maintaining good working conditions for officials and employees, stabilizing the income level, working positions, maintaining comfortable, fun but also serious working environment, managing the ideological attitude of officials and friendly working environment and also preventing loss of confidence and disturbance among colleagues. All officials and employees of the school should feel they are united to complete the common work and they also should preserve and promote the values of the same good cultural identity of their University.

\section{Leadership:}

Leadership factors affect the motivation of school officials and employees. Leaders contribute to positive changes in organizations, thus, the role of officials is maximized. Leaders play a big role in improving the motivation among all employees through listening, understanding, respecting opinions, praising, encouraging, and recognizing achievements and contributions of each team player. Recognition and appreciation of the achievements of officials and employees help them feel confident and proud of themselves. In addition, the role of a leader is expressed through support, encouragement, interest in the personal interests of both officials and employees. Leaders bring in more confidence for officials when leaders are willing to protect, support new ideas etc. Therefore, leaders need to show their role and especially their ability to protect all employees properly in case of unexpected situations. This will help officials improve overall motivation to work and dedication to the organization.

Motivating employees to work through better relations with colleagues:

Colleagues are also able to strongly impact the motivation of employees. Everyone will be more motivated to work if colleagues are willing to help each other at work, have a cheerful, relaxed attitude and work well together. Colleagues need to share experiences and thus improve professional qualifications. Colleagues create trust in teams. Having supporting and friendly colleagues is essential for increasing the reliability and efficiency of work. Therefore, the University should switch to organizing more tasks in the form requiring more group and team activities. This would contribute to building a team-working culture of mutual support. This could also indirectly support new people coming to the University to work. Besides, mass organizations such as trade unions and youth unions in cooperation with the University could organize many recreational activities and emulation movements to unite people and create cohesion, boost solidarity and so on.

\section{References:}

Alderfer, C.P. (1969). An empirical test of a new theory of human needs. Organizational Behavior and Human Performance, 4(2), 142-175.

Ambrose, M.L. \& Kulic, C.T (1999). Old friend, new faces: Motivation research in the 1990s. Journal of Management, 25(3), 231-292.

Cedefop (2012). Preventing skills' obsolescence - Rapid labour market changes leave too many workers at risk of losing their skill. Briefing Note, 1831-2411.

Hoang, T. \& Chu Nguyen, M .N. (2005). Analyzing research data with SPSS. Statistical Publishing House, Hanoi.

Linder, J.R. (1998). Understanding employee motivation. Journal of Extension, 36 (3).

Maslow, A.H. (1943). A theory of human motivation. Psychological Review, 50(4), 370-396. 
Pham Thi, M. L. (2015). Factors affecting the working motivation of small and medium enterprises in Ho Chi Minh City. Journal of Economic Development, 26 (3), 64.

Taylor, J. (2000). Nurse executive transformational leadership found in participative organizations, Journal of Nursing Administration, 30 (5), 241-250.

Tran Kim, D. (2005). Measuring job satisfaction in Vietnamese conditions. Journal of Science and Technology Development, 12, 12-19.

Truong Minh, D. (2011). Application of quantitative modeling to evaluate the level of motivation for employees of ERICSSON Co., Ltd. in Vietnam. Science magazine VNU, Economics and Business, 27, 240-247.

Paper submitted

Paper accepted for publishing

Paper published online
11 December 2019

06 February 2020

02 April 2020 